\title{
Perceptions of Members of Households Regarding the Production and Marketing of Moringa (Moringa oleifera) in Thulamela Local Municipality
}

\author{
Matume M. Maila ${ }^{1}$, Fancis D. K. Anim ${ }^{1} \&$ Khazamula P. Chauke ${ }^{1}$ \\ ${ }^{1}$ School of Agriculture, Department of Agricultural Economics and Agribusiness, University of Venda, Limpopo, \\ South Africa \\ Correspondence: Matume M. Maila, School of Agriculture, Department of Agricultural Economics and \\ Agribusiness, University of Venda, Private Bag X 5050, Thohoyandou 0950, Limpopo, South Africa. Tel: \\ 27-72-476-4055. E-mail: matumemaxmaila@gmail.com
}

Received: October 25, 2020

Accepted: March 2, $2021 \quad$ Online Published: March 15, 2021

doi:10.5539/jas.v13n4p104

URL: https://doi.org/10.5539/jas.v13n4p104

\begin{abstract}
This study was carried out to determine how members of households perceive economic benefits of production and marketing of Moringa oleifera in the Thulamela Local Municipality. The study adopted the snowball sampling procedure to identify the population of members of households who produce and market Moringa. Simple random sampling procedure was adopted to select 146 participants. The Probit regression model was used as the analytical tool for this study. The results of the study revealed amongst others, that majority of members of households who were producing Moringa had no access to Moringa markets, and most of them were aware of the economic benefits of Moringa. The statistical significant variables which influenced the perceptions of members of households regarding economic benefits of production and marketing of Moringa were level of education $(p<0.01)$, Moringa farming experience $(p<0.05)$, access to market $(p<0.05)$, as well as the access to information $(\mathrm{p}<0.05)$ about the production and the demand of Moringa produce. The study concluded that majority of respondents perceived that the production and marketing of Moringa would help to achieve sustainable livelihood for people living in Thulamela Local Municipality, while others were of the view that Moringa has the potential to improve nutrition, boost food security and foster rural development. The study recommended that establishment of Moringa markets, formation of Moringa cooperatives and promotional campaigns to educate members of households about the economic benefits of Moringa should be enhanced.
\end{abstract}

Keywords: economic benefits, marketing, moringa oleifera, production, thulamela municipality

\section{Introduction}

Moringa has gained much prominence due to its multiple uses and benefits for both agricultural and industrial development (Ashfaq et al., 2012). This attention often triggers investments and promotion campaigns to domesticate Moringa and establish large-scale commercial plantations (Achten et al., 2014). Moringa is a plant that is commonly used as a nutritional food supplement by some communities in South Africa. It has also been well approved as source of food (Pikade et al., 2013). Regarding one of the important reasons for studying development economics, is to understand how members of households can make transition out of poverty, understanding the perception of members of households regarding the improvement of Moringa production and market access are important approaches to rural development. This is because these two activities give members of households the opportunity to specialize and optimize their portfolios with respect to the available resources (Kamara, 2004).

The production and marketing of Moringa is increasingly recognised as an effective strategy for alleviating poverty and hunger, and it can be stated that a successful process of determining how members of households perceive the production and marketing of Moringa can help to promote inclusive and sustained economic growth and create decent work opportunities for members of households. According to Nadeau and Zakaria (2012) studies have equally shown that Moringa can provide excellent opportunities for agricultural producers, traders and processors, thereby making it effective in tackling micronutrient insecurity while equally holding the promise of sustainable economic returns to members of households. Moreover, Moringa production should 
stimulate market participation by members of households who produce Moringa. The current emerging trends of economic potential of Moringa as a commercial tree species suggest why it could play a role as a leading edge in the 21 st century as a veritable marketable product (Ajayi et al., 2013).

There has been an upsurge of interest in the cultivation and consumption of Moringa in South Africa and many health claims have been reported, and the government has encouraged members of households to cultivate Moringa trees in a drive to decrease malnutrition in many rural areas of South Africa (Hlophe, 2015). The burning desire to cultivate and consume Moringa has alarmed the government to embark on a campaign to encourage members of households to improve their production to commercial farming that brings about high Moringa yields and assist these households with the necessary production inputs. Taking into consideration that members of households expect immediate benefits from farming, any pathway towards sustainable Moringa production will necessarily require the inclusions of improved and predictable household productivity (Vanlauwe et al., 2014). This can only be possible by understanding how members of households view the expansion of Moringa production to a larger scale. Moreover, an analysis of sociocultural perceptions on Moringa would also provide further understanding of the behaviour of members of households regarding the tree (Gandji et al., 2018).

According to the case study compiled by NAMC (2011) commercial production of Moringa in South Africa is still at a very early stage, which makes it difficult to quantify the hectares under production, volume and value of the commodity. However, there are a few households producing the commodity as a food supplement. Empirical evidence from the study conducted by Omotesho et al. (2013) on the economics of its production highlights its potential as a tool for enhancing the income of its producers, as Moringa can be consumed and sold as a food source. This is expressing the importance of evaluating households' awareness and perception, as well as to explore more effective ways to increase its production and marketing, as most of members of households produce Moringa in their back yards, due to lack of income, knowledge and other necessary production inputs, such as improved seeds and fertilizers. According to Fadoyin et al. (2014) the productivity of Moringa has not grown sufficiently due to under-investment in new technology, slow adoption of existing improved technologies, constraints associated with investment climates and shortage of infrastructure.

Several studies have been conducted in exploring the use of Moringa for various industries (IDC, 2019). However, to date, only limited numbers of publications which seek to understand how members of households who produce Moringa can benefit from increasing Moringa productivity and marketing in rural areas are available. Therefore, this study will help to understand the major constraints which influences the perceptions of members of households regarding the production and marketing of Moringa, as well as examine how members of household perceived Moringa's production and marketing as a strategy for attaining socio-economic development in Thulamela Local Municipality.

\section{Method}

The study was conducted in the Thulamela Local Municipality, Vhembe District, Limpopo, South Africa. This is because the area is dominated by the emerging household Moringa farmers who do not have the resources to commercialize Moringa. The targeted population for this study was members of households who produce Moringa in the Thulamela Local Municipality. Simple random sampling procedure was adopted to select 146 participants for the study. Primary data was collected from members of households who produce Moringa using a designed research questionnaire. Close ended questionnaires and open-ended questionnaires were used to collect qualitative and quantitative data with the aid of thoroughly trained enumerator. The collected data was processed and examined to detect errors and omissions and corrected where possible. Based on the objectives of the study, the collected data was analysed using the IBM SPSS Statistics. Probit regression model was used as the main analytical tools for this study. Different analyses were computed to respond to the specific objectives of the study.

Specific objective, number one was to determine the socio-economic characteristics of members of households who produce Moringa in Thulamela Local Municipality. For this purpose, Cross-tabulation was used to examine the relationship between the socio-economic characteristics of members of households who produce Moringa and their level of awareness regarding the economic benefits of producing and marketing Moringa. The Test of Equality of Group Means was then used to compare two groups of members of households who produce Moringa and their respective means. In this case, members of households who are aware and those who are not aware of the economic benefits of producing and marketing Moringa were compared to find the dimensions that they differed on and each group was assessed for significance. 
Specific objective number two was to determine the perceptions of members of households regarding economic benefits of production and marketing of Moringa in Thulamela Local Municipality. For this purpose, 4-point Likert scale was used to measure the perceptions of members of households regarding economic benefits of production and marketing of Moringa. Likert scale provides independence to a participant to choose any response in a balanced and symmetric way in either directions (Joshi et al., 2015). In this study, several statements were administered to members of households to allow them to choose their responses based on whether they strongly disagree, disagree, agree or strongly agree with the statement, and respondents were not allowed to select neutral options.

Specific objective, number three was to determine factors that influence perceptions of members of households regarding economic benefits of production and marketing of Moringa in Thulamela Local Municipality. The Probit model was employed to estimate the probability of members of households' perceptions regarding economic benefits of production and marketing of Moringa. The Probit model is a statistical probability model with two categories in the dependent variable (Liao, 1994; Uzunoz \& Akcay, 2012). This study was interested on whether members of households were aware of the economic benefits of producing and marketing Moringa or not. The Probit model was more useful in this study because the dependent variable that was thought to be influenced was dichotomous.

The Probit model is a type of regression where the dependent variable can only take two values; the two possible outcomes in this study were aware and not aware denoted by 0 and 1 . With reference to the study conducted by Krystalogianni et al. (2004), the Probit model in this study provides statistically significant findings of which the predictor variables increase or decrease the probability of members of households' awareness which is estimated as:

A variable $P$ is defined so that:

$$
\operatorname{Pr}(P=1 \mid x)=\operatorname{Pr}\left(P=1 \mid x_{1}, x_{2}, \ldots x_{k}\right)
$$

$P=1$ Aware;

$P=0$ Not aware.

where, $x$ denotes the full set of explanatory variables $\left(x_{1}, x_{2}, \ldots x_{k}\right)$ which is a vector of leading indicator series in the present study. Looking at first equation, the Probit model can be interpreted as:

$$
\operatorname{Pr}(P=1 \mid x)=\mathrm{F}\left(\beta_{0}+\beta_{1 \times 1}+\ldots+\beta_{k \times k}\right)=\mathrm{F}\left(\beta_{0}+x \beta\right)
$$

where, $F$ is a function taking on values strictly between zero and one, which ensures that the estimated response probabilities are strictly between zero and one; $\beta$ is the set of coefficients corresponding to the indicator variables $x$. To make the Probit approach operational the probability of obtaining $P=1$ is linked to an unobservable index $I$. The higher the value of the index $I$ the more likely the members of households would be aware of the economic benefits of producing and marketing Moringa. The unobservable index $I$, which is required to be normally distributed for a Probit to apply, is determined by the set of explanatory variables $x$ :

$$
I=\beta_{0}+x \beta
$$

A threshold value is also required to indicate the possible occurrence of awareness. If the estimated $I$ is greater than a threshold value $I^{*}$, then $T=1$ :

$$
\operatorname{Pr}(T=1 \mid x)=\operatorname{Pr}\left(I^{*} \leq I\right)=\operatorname{Pr}\left(I^{*} \leq \beta_{0}+x \beta\right)
$$

The Probit model will estimate the coefficients $\beta_{0}$ and $\beta$ and the unobservable series $I$. Once an estimate for $I$ is obtained one can accept $P=1$ : (Awareness) if $I$ is greater than $I^{*}$, the threshold value of $I$. The normality assumption for the unobservable index $I$ means that one can obtain the probability that $I^{*} \leq I$ from the standardized normal cumulative density function. Therefore:

Where, $p \sim \mathrm{N}(0,1)$.

$$
\operatorname{Pr}\left(I^{*} \leq I\right)=\frac{1}{\sqrt{2 \pi}} \int_{-\infty}^{\mathrm{I}} e^{-t^{2} / 2} \mathrm{~d} t=\frac{1}{\sqrt{2 \pi}} \int_{-\infty}^{\beta_{0}+\beta x} e^{-t^{2} / 2} \mathrm{~d} t
$$

The probability of a being aware $\operatorname{Pr}(\mathrm{P}=1)$ is therefore measured by the area of the standard normal cumulative curve from $-\infty$ to $I$. Awareness, therefore, will be more likely to occur the larger the value of $I$. Equation 5 shows the probability that a standard normal variable ( $I$ in this case) will be less than or equal to the threshold $I^{*}$.

\section{Results}

This section presents the results of the socio-economic characteristics of members of households who produce Moringa, and their perceptions regarding the production and marketing of Moringa in Thulamela Local 
Municipality.The findings of the study revealed that majority of members of households who were producing Moringa had formal education, and most of them were aware of the economic benefits of Moringa. The study found that there was less participation of youth in the production of Moringa in the study area, and majority of respondents were either married or in a cohabiting relationship.

The production of Moringa in the Thulamela Local Municipality was dominated by members of households who produced Moringa below the average of $53 \mathrm{~kg}$ per year, moreover, majority of them had less than 4 Moringa trees in their households. The study revealed that most respondents in the study area had knowledge and experience in the production of Moringa and they have been cultivating Moringa for more than 2 two years. Access to Moringa market was a major concern in the study area, members of households had negative perception about the production of Moringa due to lack of market. Most of the members of households in Thulamela Local Municipality received information about the production and the demand of Moringa from their friends and relatives due to poor access to extension services on Moringa.

Table 1. Description of variables

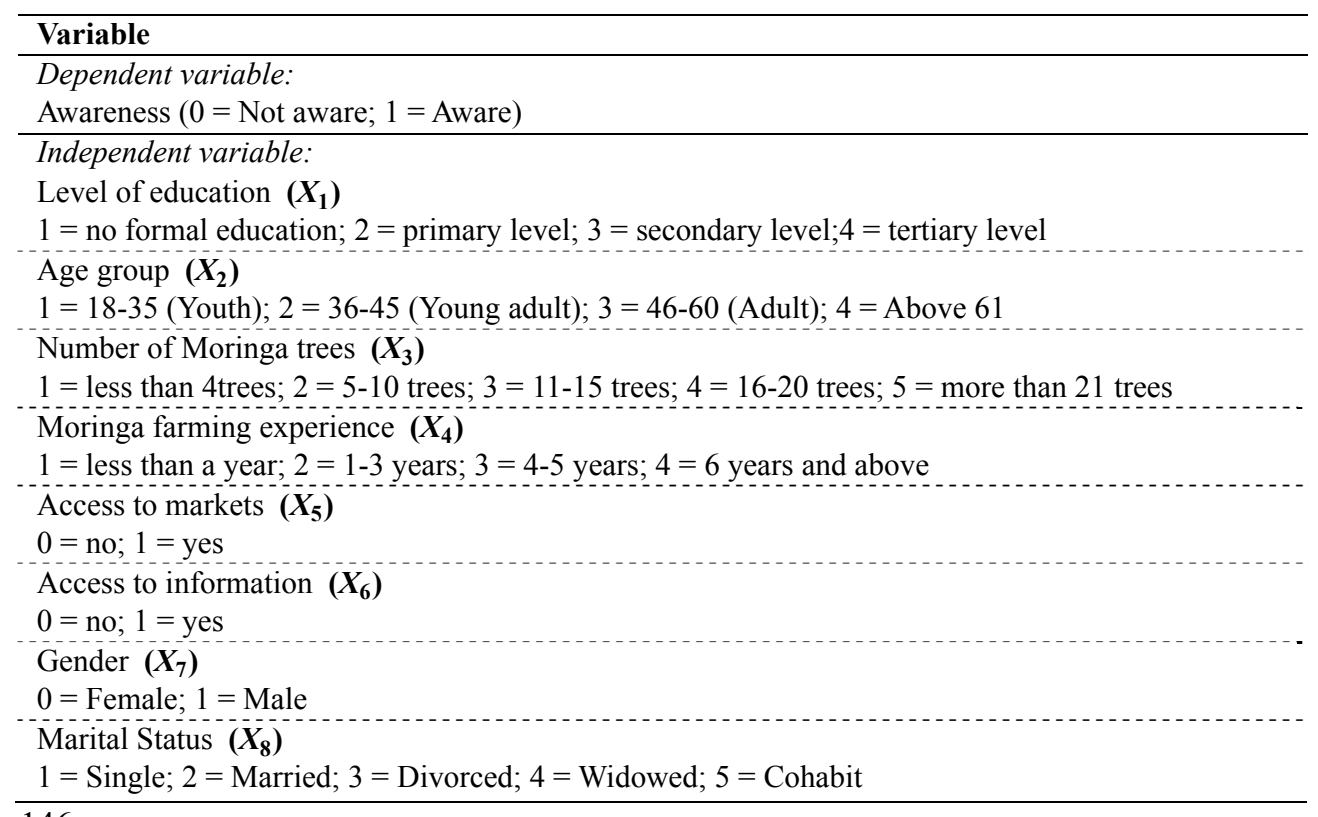

Note. $\mathrm{N}=146$.

Table 1 provides the general description of variables collected from members of households who are producing Moring in Thulamela Local municipality. The dependent variable in this study was the awareness of the economic benefits of producing Moringa. Eight (8) independent variables such as level of education, age group, number of Moringa trees, moringa farming experience, access to markets, access to information, gender, and marital Status were computed to test whether they have a significant impact on the awareness of economic benefits of producing Moringa.

Table 2. Test of equality of group means

\begin{tabular}{lllllllll}
\hline Variables & Not aware & Aware & Pooled & Wilk's $\lambda$ & $F$ & $d f 1$ & $d f 2$ & $P$-value \\
\hline EDU $\left(\boldsymbol{X}_{\mathbf{1}}\right)$ & 2.34 & 2.39 & 2.38 & 0.999 & 0.109 & 1 & 144 & 0.741 \\
AGE $\left(\boldsymbol{X}_{\mathbf{2}}\right)$ & 2.93 & 2.38 & 2.55 & 0.941 & 8.976 & 1 & 144 & 0.003 \\
NMT $\left(\boldsymbol{X}_{\mathbf{3}}\right)$ & 1.59 & 2.67 & 2.34 & 0.893 & 17.230 & 1 & 144 & 0.000 \\
MFE $\left(\boldsymbol{X}_{\mathbf{4}}\right)$ & 1.89 & 2.29 & 2.17 & 0.964 & 5.348 & 1 & 144 & 0.022 \\
ACMK $\left(\boldsymbol{X}_{\mathbf{5}}\right)$ & 0.09 & 0.33 & 0.26 & 0936 & 9.890 & 1 & 144 & 0.002 \\
INFAM $\left(\boldsymbol{X}_{\mathbf{6}}\right)$ & 0.23 & 0.75 & 0.59 & 0.767 & 43.799 & 1 & 144 & 0.000 \\
GEN $\left(\boldsymbol{X}_{\mathbf{7}}\right)$ & 0.50 & 0.46 & 0.47 & 0.999 & 0.187 & 1 & 144 & 0.666 \\
MRTS $\left(\boldsymbol{X}_{\mathbf{8}}\right)$ & 3.48 & 3.07 & 3.19 & 0.986 & 1.979 & 1 & 144 & 0.062 \\
\hline
\end{tabular}


Table 2 presented above measured the equality of group of means of independent variables between the members of households who are aware of the economic benefits of Moringa and those who are not aware. It can be observed from the test of group of equality of means that, there was a significant difference between socio economic variables at 1 percent, 5 percent and 10 percent level. A significant difference was observed at 1 percent level between independent variables such as Age group (AGE), number of Moringa trees (NMT) produced by members of households, access to information (INFAM) as well as access to Moringa market (ACMK). Moringa farming experience (MFE) showed a significant difference at 5 percent level, while the marital status (MRTS) showed a significant difference at 10 percent level.

Based on the results of test of groups of equality of means presented on Table 2 above, the age group mean scores of members of households who were aware of the economic values of Moringa (2.38) was lower than those who were not aware (2.93). These results also indicated that there was a statistically significant difference between group means at 1 percent. The significant difference implied that members of households who were not aware of the economic benefits associated with the production of Moringa were elderly people; this might be because most elders are not familiar with modern technologies compared to modern generation who can familiarise themselves with different communication channels which can assist them to gain knowledge on how Moringa can be utilised.

The results presented on Table 2 indicated that there was a significant difference in the mean scores at 10 percent level. The marital status mean scores of members of households who were not aware of the economic benefits of Moringa (3.48) was higher than those who were aware (3.07). Access to information showed a statistically significant difference in the mean scores of members of households who were aware and those who were not aware at 10 percent. The mean scores of access to information showed that members of households who were aware of the economic values of Moringa had a greater mean ( 0.75$)$ compared to their counterpart $(0.23)$.

Table 3. Parameter estimates of the Probit model

\begin{tabular}{lllll}
\hline Variables & Coefficients & Std. Error & $z$-Statistics & P-value \\
\hline Level of education $\left(\boldsymbol{X}_{\mathbf{1}}\right)$ & $-1.053^{*}$ & 0.227 & -4.643 & 0.000 \\
Age group $\left(\boldsymbol{X}_{\mathbf{2}}\right)$ & -0.644 & 0.414 & -1.555 & 0.120 \\
Number of Moringa trees $\left(\boldsymbol{X}_{\mathbf{3}}\right)$ & -0.686 & 0.511 & -1.342 & 0.180 \\
Moringa farming experience $\left(\boldsymbol{X}_{\mathbf{4}}\right)$ & $1.198^{* *}$ & 0.511 & 2.343 & 0.019 \\
Access to markets $\left(\boldsymbol{X}_{\mathbf{5}}\right)$ & $2.180^{* *}$ & 1.063 & 2.050 & 0.040 \\
Access to information $\left(\boldsymbol{X}_{\mathbf{6}}\right)$ & $1.364^{* *}$ & 0.693 & 1.968 & 0.049 \\
\hline
\end{tabular}

Note. $* \mathrm{p}<0.01 ; * \mathrm{p}<0.05 ; \mathrm{N}=146$.

Table 3 above presents the estimated coefficients for Probit regression equations. The Probit model was employed to estimate the probability of members of households' perceptions regarding economic benefits of production and marketing of Moringa. In this case, the study was interested on whether or not the perceptions of members of households were influenced by predictor variables. The estimated coefficients and standard error showed which factors influence the perceptions of members of households regarding the production and marketing or Moringa. The Probit model in this study was significant at 1 percent level of probability, and the likelihood test statistic results of the model showed that access to market, Moringa farming experience and access to information were statistically significant at 1 percent and 5 percent level of probability. The results also showed that level of education has negative and statistically significant (1 percent) effect on awareness of economic benefits of producing and marketing Moringa. 
Table 4. The rising demand of Moringa

\begin{tabular}{|c|c|c|c|c|c|c|c|}
\hline \multicolumn{8}{|c|}{ The rising demand of Moringa can help to achieve sustainable livelihoods } \\
\hline & & & Strongly disagree & Disagree & Agree & Strongly agree & Total \\
\hline \multirow{4}{*}{$\begin{array}{l}\text { Awareness of economic } \\
\text { benefits of Moringa }\end{array}$} & \multirow{2}{*}{ Not Aware } & $\mathrm{N}$ & $1+\ldots$ & 2 & 29 & 12 & 44 \\
\hline & & Sub-total & $0.7 \%$ & $1.4 \%$ & $19.9 \%$ & $8.2 \%$ & $30.1 \%$ \\
\hline & \multirow{2}{*}{ Aware } & $\mathrm{N}$ & 0 & 2 & 51 & 49 & 102 \\
\hline & & Sub-total & $0.0 \%$ & $1.4 \%$ & $34.9 \%$ & $33.6 \%$ & $69.9 \%$ \\
\hline \multirow{2}{*}{ Total } & & $\mathrm{N}$ & 1 & 4 & 80 & 61 & 146 \\
\hline & & Total & $0.7 \%$ & $2.8 \%$ & $54.8 \%$ & $41.8 \%$ & $100.0 \%$ \\
\hline
\end{tabular}

Source: Survey data (2018).

Table 4 above indicated that most (34.9 percent) of members of households who were aware of the economic benefits of producing Moringa in the study area agreed that the rising demand of Moringa products can help to achieve sustainable livelihoods for people living in rural areas, followed by 33.6 percent of respondents who strongly agreed to the same statement. The study conducted by Mabapa et al. (2017) found that Moringa production has a high commercial value thus making its cultivation a potential cash earning opportunity that can enhance the livelihoods of rural dwellers in the province. The study revealed that about 36.3 percent and 33.6 percent of respondents who were aware of economic benefits of Moringa agreed and strongly agreed that Moringa has the potential to improve nutrition, boost food security and foster rural development. Only 1.4 percent of members of households disagreed with the statement.

Table 5. Potential of Moringa

\begin{tabular}{|c|c|c|c|c|c|c|c|}
\hline \multicolumn{8}{|c|}{ Moringa has the potential to improve nutrition and boost food security } \\
\hline & & & Strongly disagree & Disagree & Agree & Strongly agree & Total \\
\hline \multirow{4}{*}{$\begin{array}{l}\text { Awareness of economic } \\
\text { benefits of Moringa }\end{array}$} & \multirow{2}{*}{ Not aware } & $\mathrm{N}$ & 0 & 2 & 29 & 13 & 44 \\
\hline & & Sub-total & $0.0 \%$ & $1.4 \%$ & $19.9 \%$ & $8.9 \%$ & $30.1 \%$ \\
\hline & \multirow{2}{*}{ Aware } & $\mathrm{N}$ & 0 & 0 & 53 & 49 & 102 \\
\hline & & Sub-total & $0.0 \%$ & $0.0 \%$ & $36.3 \%$ & $33.6 \%$ & $69.9 \%$ \\
\hline \multirow{2}{*}{ Total } & & $\mathrm{N}$ & 0 & 2 & 82 & 62 & 146 \\
\hline & & Total & $0.0 \%$ & $1.4 \%$ & $56.2 \%$ & $42.5 \%$ & $100.0 \%$ \\
\hline
\end{tabular}

Source: Survey data (2018).

The table presented above (Table 5) showed that there is a need to intensify campaigns which educate members of households about the importance and potential of Moringa in rural livelihoods, this is because within 30.1 percent of members of households who were not aware of the economic benefits of producing Moringa, 19.9 percent indicated that they agree to the statement that Moringa has the potential to improve nutrition, boost food security and foster rural development. This was also affirmed by the paper published by Agbogidi and Ilondu (2012) that expansion of Moringa production will significantly contribute to food security thereby, alleviatingpoverty and improving rural health care.

Table 6. Improving Moringa productivity

\begin{tabular}{|c|c|c|c|c|c|c|c|}
\hline \multicolumn{8}{|c|}{ Improving Moringa productivity should be linked with accessible markets } \\
\hline & & & Strongly disagree & Disagree & Agree & Strongly agree & Total \\
\hline \multirow{4}{*}{$\begin{array}{l}\text { Awareness of economic } \\
\text { benefits of Moringa }\end{array}$} & \multirow{2}{*}{ Not aware } & $\mathrm{N}$ & 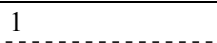 & 1 & 25 & 17 & 44 \\
\hline & & Sub-total & $0.7 \%$ & $0.7 \%$ & $17.1 \%$ & $11.6 \%$ & $30.1 \%$ \\
\hline & \multirow{2}{*}{ Aware } & $\mathrm{N}$ & 0 & 3 & 50 & 49 & 102 \\
\hline & & Sub-total & $0.0 \%$ & $2.1 \%$ & $34.2 \%$ & $33.6 \%$ & $69.9 \%$ \\
\hline \multirow{2}{*}{ Total } & & $\mathrm{N}$ & 1 & 4 & 75 & 66 & 146 \\
\hline & & Total & $0.7 \%$ & $2.8 \%$ & $51.4 \%$ & $45.2 \%$ & $100.0 \%$ \\
\hline
\end{tabular}

Source: Survey data (2018). 
Improving productivity of Moringa should always be associated with accessible market for the accumulation of profit. This statement was supported by 34.2 percent and 33.6 percent of members of households who were aware of the economic benefits of producing Moringa in the Thulamela Local Municipality. In the study conducted by Omotesho et al. (2013) market uncertainty was found to be one of the major challenges to the large-scale cultivation of Moringa in developing countries. This implied that accessible Moringa market is crucial in the advancement of Moringa. The results presented above (Table 6) also indicated that among 30.1 percent of respondents who were not aware of economic benefits of Moringa, 17.1 percent 11.6 percent agreed and strongly agreed respectively to the statement that improving productivity of Moringa should always be associated with accessible market for moringa. A total of 51.4 percent and 45.2 agreed and strongly agreed with the same statement respectively, while only 0.7 percent and 2.8 percent of respondents disagreed and strongly disagreed with the statement.

\section{Discussion}

As noted in Table 3 above, members of households who had no formal education were less likely to be aware of the economic benefits of producing and marketing Moringa. These results implied that the level of education had a negative significant impact on the perceptions of members of households regarding the production and marketing of Moringa in the study area. It was affirmed by the study conducted by Azeez et al. (2013) which revealed that Moringa farmers that had a primary education were more technically efficient in Moringa production than those with no formal education.

Moringa farming experience was one of the factors influencing the perceptions of members of households regarding the production and marketing of Moringa in the study area. The results of the study presented on Table 3 showed that members of households who had knowledge and experience in the production and marketing of Moringa were more likely to be aware of the economic benefits of producing and marketing Moringa. These results revealed that the farming experience in Moringa production had a positive impact on how members of households perceived the production and marketing of Moringa in the Thulamela Local Municipality.

The results of the study revealed that perceptions of members of households on Moringa production and marketing was influenced by access to its market. As per the results of the study (Table 3), members of households who had access to Moringa markets where more likely to be aware of the economic benefits they can derive from the production and marketing of Moringa. The study conducted by Mabapa et al. (2017) found that most farmers are willing to expand their Moringa production, but they are finding it difficult due to lack of effective market. This implies that members of households had positive perceptions on how they can utilise Moringa for socio economic benefits, therefore, the challenge of effective market access has to be addressed.

The results of the study presented on Table 3 showed that members of households who had access to information about the demand of Moringa were more likely to be aware of the economic benefits of producing and marketing Moringa. These results implied that access to information about the demand of Moringa by members of households had a positive significant impact on how members of households in the Thulamela Local Municipality perceived the production and marketing of Moringa.

\section{Conclusion}

From the results of the study, it can be concluded that members of households had positive perception about the production and marketing of Moringa in Thulamela Local Municipality as majority of respondents perceived that the production and marketing of Moringa would help to achieve sustainable livelihood for people living in Thulamela Local Municipality, while others were of the view that Moringa has the potential to improve nutrition, boost food security and foster rural development. It can also be concluded that, members of households who had no formal education were less likely to be aware of the economic benefits of producing and marketing Moringa. Furthermore, members of households who had access to information about the demand of Moringa were more likely to be aware of the economic benefits of producing and marketing Moringa. The production of Moringa in the Thulamela Local Municipality was mainly dominated by members of households who produced Moringa below average.

\section{Recommandations}

To effectively increase the production and marketing of Moringa in Thulamela Local Municipality, the study recommended that establishment of Moringa market, formation of Moringa cooperatives and promotional campaigns to educate members of households about the economic benefits of Moringa should be enhanced. Members of households who are aware of the economic benefits of Moringa should be encouraged through the provision of necessary inputs. Further studies should be done on similar topic to address the gaps. 


\section{Acknowledgements}

The author would like to acknowledge the Department of Agriculture, Forestry, and Fisheries (DAFF) for funding this research project. Your financial support enhanced the success of this research project without hardships.

\section{References}

Achten, W. J., Sharma, N., Muys, B., Mathijs, E., \& Vantomme, P. (2014). Opportunities and Constraints of Promoting New Tree Crops-Lessons Learned from Jatropha. Sustainability, 6. https://doi.org/10.3390/ su6063213

Ajayi, F. O., \& Adeyemi, A. A. (2016). Factors Influencing the Adoption of Moringa Plant Cultivation Among Farming Households In Southwestern Nigeria: A Tobit Approach. International Journal of Innovative Food, Nutrition \&Sustainable Agriculture, 4(4), 15-24.

Ashfaq, M., Basra, S. M. A., \& Ashfaq, U. (2012). Moringa: A Miracle Plant of Agroforestry. Journal of Agriculture \& Social Sciences, 8, 115-122.

Azeez, F. A., Nosiru, M. O., Clement, N. A., Awodele, D. A., Ojo, D., \& Arabomen, O. (2013). Importance of Moringa Oleifera tree to human livelihood: A case study of Isokan local government area in Osun state. Elixir Agriculture, 55, 12959-12963.

Fadoyin, A. S., Ayanrinde, F. A., Majolagbe, M. O., Baba, G. O., Erhabor, T. A., \& Sulaiman, Y. D. (2014). Assessment of Socio-Economic Factors Influencing Adoption of Agricultural Innovation by Farmers in Kaduna State. International Journal of Agriculture and Biosciences, 3(1), 41-44.

Gandji, K., Chadare, F. J., Idohou, R., Salako, V. K., Assogbadjo, A. E., \& Glèlè Kakaï, R. L. (2018). Status and Utilisation of Moringa oleifera Lam: A REVIEW. African Crop Science Journal, 26(1), 137-156. https://doi.org/10.4314/acsj.v26i1.10

Hlophe, S. N. (2015). Utilisation of Moringa Oleifera (Moringa) and Pennisetum Clandestinum (Kikuyu) leaf meals by three commonly cultured fish species in South Africa: Tilapia Rendalli, Oreochromis Mossambicus and Clarias Gariepinus (Research thesis, University of Limpopo, South Africa).

Industrial Development Corporation of South Africa. (2019). Growing and Agro-Processing of Moringa oleifera with commercial potential in South Africa. Sandton: South Africa.

Kamara, A. B. (2004). The impact of market access on input use and agricultural productivity: evidence from Machakos district, Kenya. Agrekon, 43(2). https://doi.org/10.1080/03031853.2004.9523645

Liao, T. F. (1994). Interpreting Probability Models: Logit, Probit, and Other Generalized Linear Models. Quantitative Applications in the Social Sciences (p. 101). Sage Publications, Thousand Oaks, Calif, USA.

Mabapa, M. P., Ayisi, K. K., Mariga, I. K., Mohlabi, R. C., \& Chuene, R. S. (2017). Production and utilization of Moringa by farmers in Limpopo province, South Africa. Int. J. Agric. Res., 12, 160-171. https://doi.org/ 10.3923/ijar.2017.160.171

Nadeau. E., \& Zakaria, M. (2012). The Sahel's Tree of Life: The Story of CLUSA's Moringa VC Project in Niger. Working paper prepared for the National Cooperative Business Association (NCBA) and the Cooperative League of the USA (CLUSA).

National Agricultural Marketing Council. (2011) Moringa Oleifera A Tree Giving Life to Rural Communities. Moringa case study. Pretoria: South Africa.

Omotesho, K. F., Sola-Ojo, F. E., Fayeye, T. R., Babatunde, R. O., Otunola, G. A., \& Aliyu, T. H. (2013). The potential of Moringa tree for poverty alleviation and rural development: Review of evidences on usage and efficacy. International Journal of Development and Sustainability, 2(2), 799-813.

Pikade, V., Cukrowska, E., \& Chimuka, L. (2013). Metal and flavonol contents of Moringa oleifera grown in South Africa. S. Afr. J. Sci., 109(3/4), 7. https://doi.org/10.1590/sajs.2013/835

Uzunoz, M., \& Akcay, Y. (2012). A Case Study of Probit Model Analysis of Factors Affecting Consumption of Packed and Unpacked Milk in Turkey. Economics Research International, 8. https://oi.org/10.1155/ 2012/732583

Vanlauwe, D., Coyne, D., Gockowski, J., Hauser, S., Huising, J., Masso, C., ... Van Asten, P. (2014). Sustainable intensification and the African smallholder farmer. Current Opinion in Environmental Sustainability, 8, 15-22. https://doi.org/10.1016/j.cosust.2014.06.001 


\section{Copyrights}

Copyright for this article is retained by the author(s), with first publication rights granted to the journal.

This is an open-access article distributed under the terms and conditions of the Creative Commons Attribution license (http://creativecommons.org/licenses/by/4.0/). 